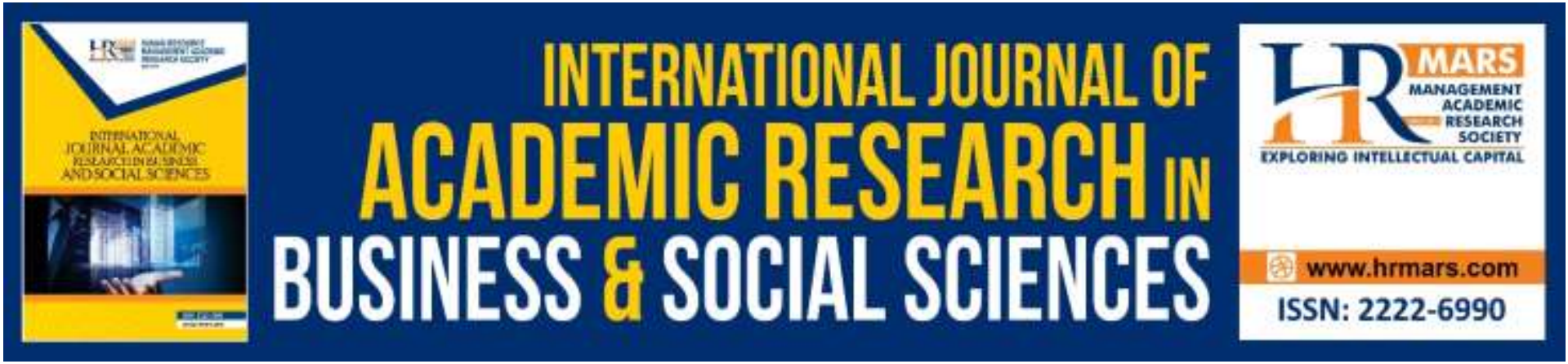

\title{
An Idea for Compensating Local Farmers for a Sustainable Method of Pineapple Farming
}

\section{Adrian Daud, Shairil Izwan Taasim \& Anita Rosli}

To Link this Article: http://dx.doi.org/10.6007/IJARBSS/v11-i17/11405 DOI:10.6007/IJARBSS/v11-i17/11405

Received: 07 August 2021, Revised: 25 August 2021, Accepted: 19 September 2021

Published Online: 16 October 2021

In-Text Citation: (Daud et al., 2021)

To Cite this Article: Daud, A., Taasim, S. I., \& Rosli, A. (2021). An Idea for Compensating Local Farmers for a Sustainable Method of Pineapple Farming. International Journal of Academic Research in Business and Social Sciences, 11(17), 237-245.

Copyright: (C) 2021 The Author(s)

Published by Human Resource Management Academic Research Society (www.hrmars.com) This article is published under the Creative Commons Attribution (CC BY 4.0) license. Anyone may reproduce, distribute, translate and create derivative works of this article (for both commercial and non-commercial purposes), subject to full attribution to the original publication and authors. The full terms of this license may be seen at: http://creativecommons.org/licences/by/4.0/legalcode

Special Issue Title: Empowering Community and Beyond, iRandau, 2021, Pg. 237 - 245

Full Terms \& Conditions of access and use can be found at http://hrmars.com/index.php/pages/detail/publication-ethics 


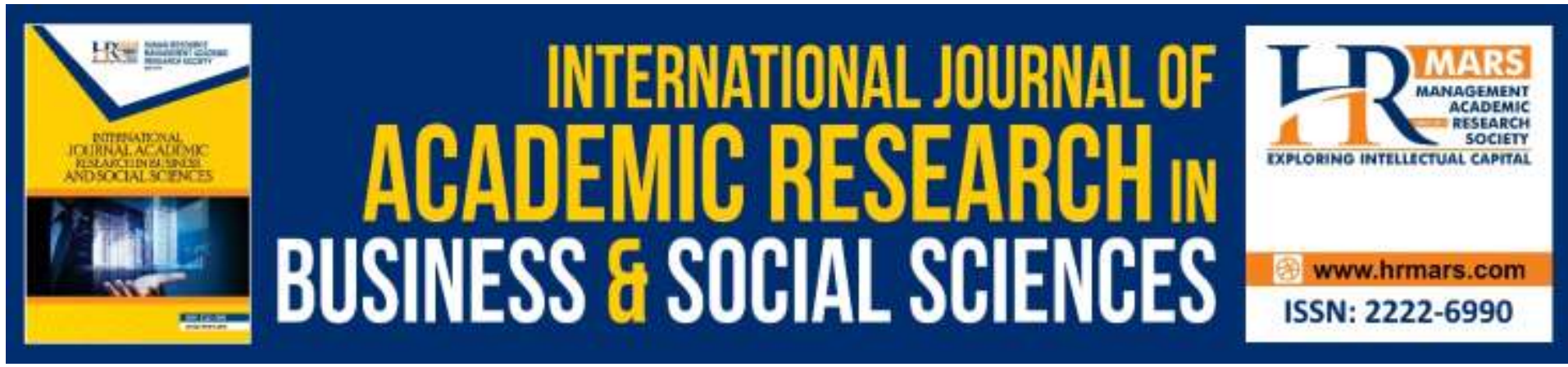

\title{
An Idea for Compensating Local Farmers for a Sustainable Method of Pineapple Farming
}

\author{
Adrian Daud ${ }^{1,2}$, Shairil Izwan Taasim ${ }^{1} \&$ Anita Rosli ${ }^{1,2}$ \\ ${ }^{1}$ Department of Social Science and Management, Faculty of Humanities, Management and \\ Science, Universiti Putra Malaysia Bintulu Sarawak Campus, Nyabau Road, 97008 Bintulu, \\ Sarawak, Malaysia, ${ }^{2}$ Institut Ekosains Borneo, Universiti Putra Malaysia Bintulu Sarawak \\ Campus, 97008 Bintulu, Sarawak, Malaysia \\ Email: adrian@upm.edu.my
}

\begin{abstract}
Agricultural activities have the share in contributing to greenhouse gases in the atmosphere. The method of residue burning (RB), which has been practiced in Samarahan, Sarawak in Malaysia contributed to the emission of carbon into the atmosphere. Steps should be taken to address this issue by promoting sustainable method of farming. Pineapple farmers can be given incentives to change to a more sustainable method such as zero burning (ZB) whereby a mechanism like the clean development mechanism (CDM) can be adopted at the local level to encourage farmers adopting this sustainable farming technique. This incentive is primarily derived from the value of carbon sequestered in the soil through the practice of ZB. Although farmer will suffer financial loss due to additional cost, they can be compensated for this loss under ZB. Thus, farmers still can receive better income with the compensation and at the same continuing to practice $Z B$.
\end{abstract}

Keywords: Zero Burning, Carbon Sequestration, Compensation, Sustainable Agriculture

\section{Introduction}

Agricultural activities are still important to most people in the developing countries especially in the rural areas as it can become their means of earning a living. Samarahan is situated in the coastal area of the state of Sarawak in Malaysia, an area which is known for its agricultural activities. The Integrated Agriculture Development Area (IADA) is the agency responsible to monitor the agricultural activities and to help farmers with their crop planting. Pineapple is the main crop under IADA scheme, and it has made Samarahan as one of the producers of fresh pineapple in the state. Sarawak is the second major producer of Pinapple in the country with more than 38,000 tonnes in 2017 (Borneo Post, 2019). Farmers are planting pineapple for family consumption or to be sold at the local market and this subsistence farming has been practiced for generations. These low-income farmers are dependent on the government subsidies for the expansion of their crop production and the IADA is there to help them to increase their income. 
The area planted with pineapple is made of peat soil as this kind of soil has been traditionally used for pineapple planting in Malaysia due to the adaptability of pineapple to peat soil (Py et al., 1987). However, we should be concern on the use of peat soil for agricultural activities in view of the releasing of carbon into the atmosphere. Agricultural land is found to have lower amount of carbon stored in the soil and inappropriate method of farming can lead to greenhouse effects (caused by carbon released in the atmosphere). The mechanics of soil and greenhouse gases in relation to agricultural practices depends on many factors as shown by Lal (2001a). The traditional method of pineapple farming is residue burning (RB) whereby after harvesting and taking the pineapple suckers, the residue (after being chopped) is burned. For these small-scale farmers, they have been burning the pineapple residue in the past and this would also contribute to the haze problem that is now becoming almost an annual problem in the country. Adopting a more sustainable method such as zero burning (ZB) can mitigate the release of carbon into the atmosphere and incentives could be used to encourage farmers to adopt this environmentally friendly method. As more areas are being explored for pineapple cultivation, not only in Samarahan, but other areas in the state, it is the right time to encourage farmers to use the practice of ZB in pineapple cultivation. Sustainable agriculture is becoming more important today than ever as many are warrying of the issue of global warming. Thus, ZB can be a viable option in promoting sustainable agriculture.

\section{Methodology}

In this study, we will look at the income generated by farmers under RB and then looking at the viability of adopting ZB. First, we need to establish the kind of revenue that the farmers are receiving and what are the costs that they incurred in order to know the profit they get. There are 206 farmers interviewed and we use the average value in calculating their costs and returns. Most of the farmers in Samarahan are planting the Josapine and Cayenne breed which is for the fresh fruit market. This is different from the high-density planting of the Gandul breed which is planted for canned pineapple. They are planting at a relatively lower density, which is averaging around 27,000 fruits per hectare (ha). The average output by the farmers is estimated to be about $70 \%$ of total fruits planted. This means that out of the 27000 planted, only about 18,900 are harvested, which gives the yield of 15.309 metric tonne (MT) per hectare for the farmers. The farm gate price for grade A pineapples is Ringgit Malaysia (RM) 1.00 and for grade $B$ is RM0.80 while grade $C$ pineapple is priced at RM0.50. Thus, the average price of the pineapple can be obtained by calculating the revenue from each grade of pineapple. This gives us the value of RM887.7 per MT of pineapple. Therefore, the revenue received by the farmers in Samarahan is about RM13,590 per ha for one cycle of planting. Pineapples in this area are harvested after 13 months from planting and then another 3 to 4 months for preparation of pineapple suckers. Thus, another cycle of planting will be done about 18 months after the first cycle of planting. 
Table 1: Cost structure of pineapple planting with different practices

\begin{tabular}{|c|c|c|c|c|}
\hline & \multicolumn{2}{|c|}{ Zero Burning } & \multicolumn{2}{|c|}{ Residue Burning } \\
\hline & $\begin{array}{c}\text { First cycle } \\
\left(\mathrm{RM}^{*}\right)\end{array}$ & $\begin{array}{c}\text { Subsequent } \\
\text { cycles } \\
\left(\mathrm{RM}^{*}\right)\end{array}$ & $\begin{array}{l}\text { First cycle } \\
\left(\mathrm{RM}^{*}\right)\end{array}$ & $\begin{array}{c}\text { Subsequent } \\
\text { cycles } \\
\left(\mathrm{RM}^{*}\right)\end{array}$ \\
\hline Labor Costs & & & & \\
\hline Land preparation & 1000 & 1000 & 1000 & 1000 \\
\hline Planting & 810 & 810 & 810 & 810 \\
\hline Weeding & 800 & 800 & 800 & 800 \\
\hline Fertilizer application (spray) & 450 & 450 & 450 & 450 \\
\hline Fertilizer application & 105 & 105 & 105 & 105 \\
\hline Hormone application & 150 & 150 & 150 & 150 \\
\hline Harvesting & 945 & 945 & 945 & 945 \\
\hline Residue racking \& stacking of leaves & 500 & 500 & 0 & 0 \\
\hline & 4760 & 4760 & 4260 & 4260 \\
\hline Material Costs & & & & \\
\hline Suckers & 5400 & 0 & 5400 & 0 \\
\hline NPK Fertilizer & 1764 & 1764 & 1764 & 1764 \\
\hline Urea & 243.6 & 243.6 & 243.6 & 243.6 \\
\hline Hydrated lime & 49 & 49 & 49 & 49 \\
\hline Cuprum sulfate & 40.6 & 40.6 & 40.6 & 40.6 \\
\hline Zinc sulfate & 29 & 29 & 29 & 29 \\
\hline Ferum sulfate & 18.85 & 18.85 & 18.85 & 18.85 \\
\hline NAA Hormone & 110 & 110 & 110 & 110 \\
\hline Parakuat (clearing) & 35 & 35 & 35 & 35 \\
\hline Gesapex (weeding) & 348 & 348 & 348 & 348 \\
\hline Sum & 8038.05 & 2638.05 & 8038.05 & 2638.05 \\
\hline Total Costs & $12,798.05$ & 7398.05 & $12,298.05$ & 6898.05 \\
\hline
\end{tabular}

*Note: Ringgit Malaysia (RM), RM1 = US\$

We have to convert these figures into an annual streams income for the farmers to be able to know what the farmers are earning from pineapple planting. As one cycle of planting is spread over a period of 18 months, we simplify this by taking the values given in Table 1 and divided them into 18 (months) to come up with the annual income received by the farmers. As we are suggesting the use of ZB in pineapple planting to reduce the emission of carbon dioxide, we need to look in the long run to be able to capitalize on the benefits of ZB. Resource management often looks in long run perspective and therefore we take 24 years (or 16 cycles of planting) in this case. This is in the range of the minimum period required to do analysis on the effect on natural resources. In this case it is the soil on which pineapples are planted. Then the net present value (NPV) is used to compare the income of farmers with the present $\mathrm{RB}$ and the proposed $\mathrm{ZB}$. We use the discount rate of $4 \%$ which is lower than the market rate to emphasize the long-term environmental impact. A lower rate will take into account the future benefits and is recommended for natural resource management to reflect 
that it is a long-term investment. Taking a higher discount rate (at market rate) tend to focus on the immediate gain at the early period of investment.

The benefit of using ZB is the carbon sequestration value which will be increasing over the years. The accumulation of carbon in the long run is an added benefit to society as it mitigates the release of carbon dioxide into the atmosphere. The RB practice by the farmers will deplete the carbon content in the soil through the burning of the pineapple residue at the end of the planting period. As pointed out by Jain et al. (2104), the burning of residue contributes to the release of carbon into the atmosphere as well as other greenhouse gases. Sustainable agriculture means that the resource used (i.e., soil) should be managed in a sustainable manner. The negative effects on the environment should be minimized if not avoided. Although there is no specific study on the soil carbon content of the area planted with pineapple in Samarahan, it is well known that soil carbon content for land converted for agriculture well below that of the forest (Sharma et al., 2019). Agricultural soils lost between $25-75 \%$ of its original carbon pool according to Lal (2001c). This can be between $60-80 \%$ for severely degraded soils. Wei et al. (2014) estimates on average a decrease of $41 \%$ in the tropical regions.

There are different methods to estimate carbon sequestration such as by (Lal, 2001c) Albrecht and Kandji (2003); Jepsen (2006) and recently Yang et al (2019). A decade ago, this is still at a development stage as argued by (Nair et al., 2009). The rate of accumulation of carbon is normally on the increase only after the 3rd-5th year and begins to slow down after 20 years as shown by (Lal, 2001c). The accumulation of carbon after the 25 th year may slow down but still increasing the carbon stock in the soil. In our case the base carbon is assumed to be at 45 tonne carbon $(\mathrm{tC}) /$ ha for agricultural land. Peat soil in its natural state can hold carbon up to 200tC/ha (Pearce et al., 2002; Hooijer et al., 2006) and for agriculture soil Pearce (2001) estimates the value to be at $63 \mathrm{tC} / \mathrm{ha}$. For the unconverted forest we take a moderate value of $150 \mathrm{tC} / \mathrm{ha}$ following SCBD (2001) and a $70 \%$ loss of carbon means we are left with $45 \mathrm{tC} / \mathrm{ha}$. This is well between the $40 \mathrm{tC} / \mathrm{ha}$ and $63 \mathrm{tC} /$ ha given by Unger (2001) and Pearce (2001) respectively.

Sequestration of carbon is possible through good agricultural practice (GAP) and ZB practice is one way of doing this. For $Z B$, accumulation of carbon is gradual for the first 9 years followed by a sharp increase from then on until the 20th year. After that there is a sharp decrease in the accumulation rate. This pattern of soil carbon sequestration rate is similar to what was demonstrated by Lal (2001c). Figure 1 shows the rate of soil carbon sequestration. The accumulation of soil carbon is given by Equation (1) which is the estimated function of the soil carbon sequestration. Figure 2 shows the pattern of soil carbon accumulation up to 50 years as given by Equation (1). Meanwhile RB will cause the release of carbon into the atmosphere and therefore reduce the amount of carbon in the soil. We assume that soil carbon is decreasing at an average rate of $3 \mathrm{tC} / \mathrm{ha} / \mathrm{year}$ and if $\mathrm{RB}$ continues the soil is depleted of carbon in a matter of 15 years.

$$
C_{t}=-0.09 t^{3}+0.326 t^{2}-1.787 t+45
$$

where $C_{t}$ is the estimated carbon sequestration for year $t$ 


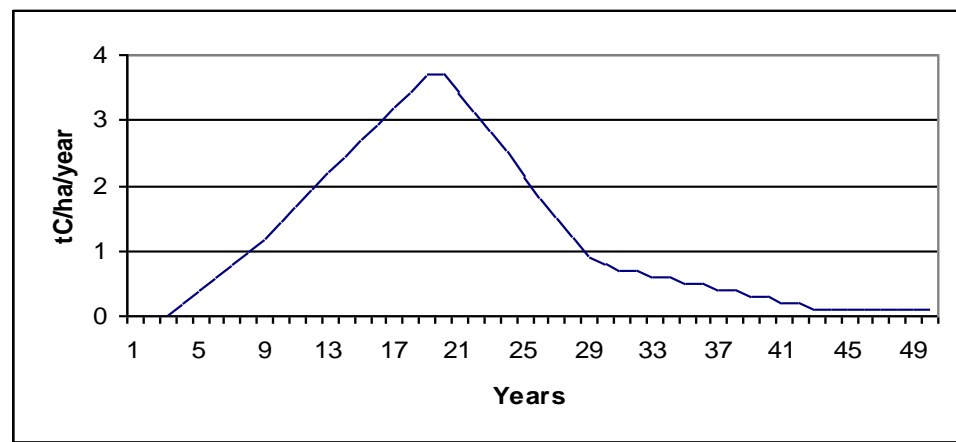

Figure 1: Rate of soil carbon sequestration

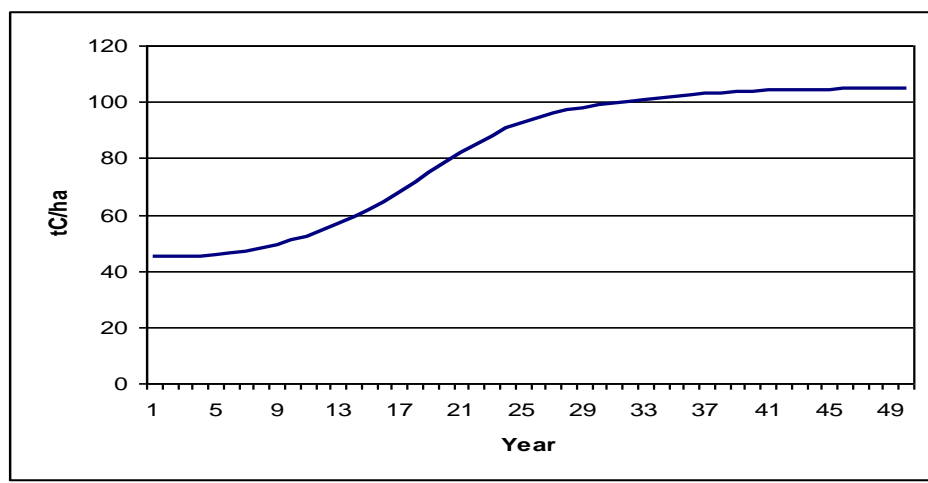

Figure 2: Accumulation of soil carbon

Carbon market is just like any other new market out there. Clarkson (2000) suggests a value of $\$ 34 / \mathrm{tC}$ and Tol et al (2000) stated that it would be difficult for it to be more than $\$ 50 / \mathrm{tC}$. This range of $\$ 34-\$ 50 / \mathrm{tC}$ can be considered high as pointed out by Pearce (2001). Zhang (2000) suggested a moderate value of $\$ 10 /$ tC which is used by Pearce (2001) considering the high value concern. However, if we take the value of carbon traded carbon market, the value is considered as quite high and in the European market for example, it is valued at EU\$20/tC (2009 price). Then, in 2015 a minimum price of EU\$13/tC has been recommended for a forest management project. For a program that seeks to compensate farmer such as in Samarahan that does not require international level program such as the Clean Cevelopment Mechanism (CDM) under the Kyoto Protocol, perhaps a moderate value of $\$ 10 / \mathrm{tC}(\mathrm{RM} 40 / \mathrm{tC})$ is already sufficient and reasonable. We will be using the rate of carbon price recommended recently for sustainable development in Malaysia (Joshi, 2019) of $\mathrm{RM} 35 / \mathrm{tC}$ in our analysis.

\section{Results and Discussions}

The revenues from the two practices are the same as farmers will be planting the same amount of pineapple if they adopt the ZB practice. The NPV of the revenues receive by farmers is RM125,237.71. The cost associated with the ZB and RB will differentiates them in terms of their returns. Then the value from carbon sequestration is different under the two practices which will determine whether $Z \mathrm{~B}$ is a preferable option over the current $\mathrm{RB}$ practice. The total costs under ZB and RB for the 24-year period are given in Table 2 . The practice of ZB shows a much higher cost because of the additional costs in residue racking and stacking of leaves as shown in Table 1 earlier. 
Table 2: NPV of total cost and carbon sequestration (per ha)

\begin{tabular}{|c|c|c|}
\hline & Total Cost & Carbon Sequestration \\
\hline Zero Burning & RM80,323.76 & RM30,311.88 \\
\hline Residue Burning & RM75,236.99 & RM10,189.23 \\
\hline
\end{tabular}

Table 3 shows the net benefits receive by farmers under the two practices. Although farmers will receive lower returns if they adopt ZB at RM44,913.95 compared to RM50,000.72 for RB, they can be compensated by the higher value of carbon sequestration under $\mathrm{ZB}$. The value of carbon sequestration under $\mathrm{ZB}$ is RM30,311.88 which should be higher since there is the accumulation of soil carbon during the 24 -year period. RB results in lower value as the soil releases carbon over the years.

Table 3: Net benefits of ZB and RB in NPV (4\%) terms (RM per ha)

\begin{tabular}{|l|c|c|c|c|}
\hline & ZB (RM) & \multicolumn{1}{|c|}{$\%$} & RB (RM) & \multicolumn{1}{c|}{$\%$} \\
\hline Pineapple Revenues & 44913.95 & $59.71 \%$ & 50000.72 & $83.07 \%$ \\
\hline Carbon Sequestration & 30311.88 & $40.29 \%$ & 10189.23 & $16.93 \%$ \\
\hline Net benefits & 75225.83 & $100.00 \%$ & 60189.23 & $100.00 \%$ \\
\hline
\end{tabular}

The percentage of carbon sequestration value from the total benefits is much higher $(40.29 \%)$ with ZB compared to RB. This means that more benefits can be derived from carbon sequestration when the price is higher. For the price of carbon, it must be priced significantly high and at RM35/tC, ZB is clearly a better option for the farmers as they can be compensated through the value of carbon. This however begs the question of whether this a viable option as there no compensation mechanism for local farmers is currently. The government should investigate the possibilities of compensating farmers through a national or state level mechanism similar to what is done under CDM at the international level (Liu, 2008). The price of carbon plays an important role in this case as it affects the attractiveness of ZB. The higher the price of carbon, then more can be gained from ZB. Carbon price is set to be higher in the future and this has been proposed by Joshi (2019) in the context Malaysia. There are CDM projects in Malaysia although most of that involve the industrial sector. Agricultural projects seem to be less attractive to potential investor if it is not a reforestation or an afforestation project. Inclusion of smallholders should be targeted in the effort to promote sustainable agriculture as most farmers in a developing country like Malaysia fall under this category.

Monetary compensation to the farmers is an incentive for them to adopt a more sustainable approach in pineapple planting. This is an incentive to promote sustainable agriculture at a smaller scale. Both the government and the private sectors should participate actively for this kind of program to materialize. A monitoring agency is required for certification and should work closely with IADA for compensation to the farmers and this will be similar to the payment for certified emission reduced (CER) under CDM. The private sectors should be encouraged to participate, and the government can give a tax incentive for them. There has to be a way to encourage farmers to move toward sustainable agriculture through GAP.

\section{Conclusions}

Sustainable agriculture can be implemented through GAP by farmers. This is looking at the long-term implication of agriculture to the environment. Agriculture has its share in 
contributing to the greenhouse gas emission worldwide. The developing countries are still dependent on agriculture and farmers in the rural areas are mainly smallholders. Their primary concern regarding farming is to meet their daily needs and this subsistence farming is common to most farmers in developing countries especially in the rural area. Their traditional method of planting involves burning of pineapple residue, which has negative impacts to the environment. This is also an easy way to get rid of the pineapple residue and it is a convenient method for them.

The idea of proposing ZB practice to the farmers is challenging as it would mean their costs has increased and thus will affect their income. More importantly there must be a mechanism that enables the farmers to be compensated for any reduction in their revenues if they adopt sustainable approach in farming. Enforcement is necessary for a mechanism that seeks to reward farmers to work properly. There must be a value for cleaner environment, and this can be used to compensate the farmers for their losses when embracing GAP in the form of ZB. This is a win-win situation in our quest to promote sustainable agriculture among farmers and at the same time increasing their income. This is a more realistic approach then asking someone to leave the land as it is to mitigate carbon emission.

\section{Reference}

Ahmed, O. H., Husni, M. H. A., Anuar, A. R., \& Hanafi, M. M. (2002) Effect of Residue Management Practices on Yield and Economic Viability of Malaysian Pineapple Production. Journal of Sustainable Agriculture, 20 (4), pp. 83-93.

Albrecht, A., \& Kandji, S. T. (2003) Carbon sequestration in tropical agroforestry systems. Agriculture, Ecosystems and Environment, 99, pp.15-27.

Borneo Post Online. (2019). Big Potential for Pineapple Farming in Sarawak. https://manred.sarawak.gov.my/modules/web/pages.php?mod=news\&sub=news_vi ew\&nid=194

Clarkson, R. (2000). Estimating the Social Cost of Carbon Emissions. London Department of the Environment, Transport, and the Regions. London: HM Treasury.

Department of Agriculture (DOA). (2005). Perangkaan Pertanian Sarawak 2005. DOA Sarawak.

Hooijer, A., Silvius, M., Wosten, H., \& Page, S. (2006). PEAT-CO2 Assessment of CO2 emissions from drained peatlands in South-East Asia. WL Delft Hydraulics Report Q3943.

Jepsen, M. R. (2006). Above-ground carbon stocks in tropical fallows, Sarawak, Malaysia. Forest Ecology and Management, 225, 2pp. 87-295.

Jain, N., Bhaitia, A., \& Pathak, H. (2014). Emission of Air Pollutants from Crop Residue Burning in India. Aerosol and Air Quality Research, 14: 422-430.

Joshi, D. (2019). Using Carbon Pricing to Support Sustainable Development in Malaysia. Monographs of Penang Institute.

Lal, R. (2001a). Soils and the Greenhouse Effect. In: Soil Carbon Sequestration and the Greenhouse Effect (eds Lal, R., W.A. Dick, J.M. Bartels), pp. 1-8, Soil Science Society of America (SSSA) Special Publication No. 57, Madison, WI.

Lal, R. (2001b) Myths and Facts About Soils and the Greenhouse Effect. In: Soil Carbon Sequestration and the Greenhouse Effect (eds Lal, R., W.A. Dick, J.M. Bartels), pp. 926, Soil Carbon Sequestration and the Greenhouse Effect. Soil Science Society of America (SSSA) Special Publication No. 57, Madison, WI. 
Lal, R. (2001c). The Potential of Soil Carbon Sequestration in Forest Ecosystem to Mitigate the Greenhouse Effect. In: Soil Carbon Sequestration and the Greenhouse Effect (eds Lal, R., W.A. Dick, J.M. Bartels), pp. 137-154. Soil Science Society of America (SSSA) Special Publication No. 57, Madison, WI., pp.

Liu, X. (2008). The monetary compensation mechanism: An alternative to the clean development mechanism. Ecological Economics, 66, pp. 289-297.

Nair, P. K. R., Kumar, B. M., \& Nair, V. D. (2009) Agroforestry as a strategy for carbon sequestration. Journal of Plant Nutrition and Soil Science, 172, pp. 10-23.

O'Connor, D. (2008). Governing the global commons: Linking carbon sequestration and biodiversity conservation in tropical forests. Global Environmental Change, 18 (3), pp. 368-374.

Pearce, D. (2001). The economic value of forest ecosystem. Ecosystem Health, 7 (4), pp. 284296.

Py, C., Lacoeuilhe, J. J., \& Teissen, C. (1987). The Pineapple Cultivation and Uses. G.P. Maisounneuve et Larose: Paris.

Secretariat of the Convention on Biological Diversity, (2001). The Value of Forest Ecosystem, Montreal, SCBD, 67p. (CBD Technical Series no. 4).

Sharma, G., Sharma, L. K., \& Sharma, K. C. (2019). Assessment of land use change and its effect on soil carbon stock using multitemporal satellite data in semiarid region of Rajashtan, India. Ecological Processes, 8(42). https://doi.org/10.1186/s13717-0190193-5

Tisdell, C. (1999). Conservation farming and indicators of agricultural sustainability. Chapter 5 in Sustainable Agriculture and Environment: Globalisation and the Impact of Trade Liberalisation (eds Dragun, A.K. and Tisdel, C.), pp. 57-78. Edward Elgar: UK.

Tol, R., Fankhauser, S., Richels, R., \& Smith, J. (2000), How much damages will climate change do? Recent estimates. World Economics, 1 (4), pp. 179-206.

Unger, P. W. (2001), Total Carbon, Aggregation, Bulk Density, and Penetration Resistance of Cropland and Nearby Grassland Soils. In Soil Carbon Sequestration and the Greenhouse Effect (eds Lal, R., W.A. Dick, J.M. Bartels), pp. 77-92. Soil Science Society of America (SSSA) Special Publication No. 57, Madison, WI.

Zhang, Z. X. (2000). Estimating the Size of the Potential Market for the Kyoto Flexibility Mechanisms. Faculty of Law and Faculty of Economics, University of Gronigen, mimieo.

Wei, X., Shao, M., Gale, W., \& Li, L. (2014). Global pattern of soil carbon losses due to the conversion of forests to agricultural land. Scientific Reports 4, 4062. https://doi.org/10.1038/srep04062

Yang, Y., Tilman, D., Furey, G., \& Lehman, C. (2019). Soil carbon sequestration accelerated by restoration of grassland biodiversity. Nature Communications 10, 718. https://doi.org/10.1038/s41467-019-08636-w 